\title{
Newly discovered reefs in the southern Abrolhos Bank, Brazil: Anthropogenic impacts and urgent conservation needs
}

\author{
E.F. Mazzei ${ }^{\text {a,b,* }}$, A.A. Bertoncini ${ }^{\text {c,d }}$, H.T. Pinheiro ${ }^{\text {a,b,e,j }}$, L.F. Machado ${ }^{\text {d,f }}$, C.C. Vilar ${ }^{\text {a }}$, H.C. Guabiroba ${ }^{\text {a }}$, T.J.F. Costa ${ }^{\text {b }}$, \\ L.S. Bueno ${ }^{\text {d,g }}$, L.N. Santos ${ }^{\text {c }}$, R.B. Francini-Filho ${ }^{\text {h}}$, M. Hostim-Silva ${ }^{\text {d,i }}$, J.-C. Joyeux ${ }^{\text {a }}$ \\ a Departamento de Oceanografia e Ecologia, Universidade Federal do Espírito Santo, Vitória, ES, Brazil \\ b Associação Ambiental Voz da Natureza, Brazil \\ c Programa de Pós-Graduação em Ciências Biológicas (Biodiversidade Neotropical), Universidade Federal do Estado do Rio de Janeiro, Rio de Janeiro, RJ, Brazil \\ 'Instituto Meros do Brasil, Curitiba, PR, Brazil \\ e California Academy of Sciences, San Francisco, CA, USA \\ f Departamento de Morfologia, Instituto de Biociências, Universidade Estadual Paulista, Botucatu, SP, Brazil \\ ' Instituto COMAR-Conservação Marinha do Brasil, Joinville, SC, Brazil

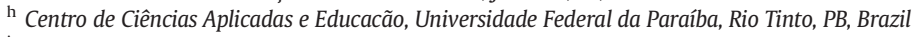 \\ i Centro Universitário Norte do Espírito Santo, Universidade Federal do Espírito Santo, São Mateus, ES, Brazil \\ ${ }^{\mathrm{j}}$ Ecology and Evolutionary Biology Department, University of California Santa Cruz, CA, USA
}

\section{A R T I C L E I N F O}

\section{Article history:}

Received 5 April 2016

Received in revised form 18 August 2016

Accepted 24 August 2016

Available online 15 September 2016

\section{Keywords:}

Abrolhos Bank

Coral reefs

Reef fishes

Conservation

Mining dam collapse

Environmental impact

\begin{abstract}
A B S T R A C T
The Abrolhos Bank is an area of high ecological, socio-economic importance and harbour the richest and mostextensive coral reefs in the South Atlantic. Here we report the discovery of shallow (12-25 m depth) reef complex with ten large biogenic structures, intermediate between the typical mushroom-shaped pinnacles of the northern Abrolhos Bank $\left(17^{\circ}-18^{\circ} \mathrm{S}\right)$ and the small patch reefs found on the central/southern coast of the Espírito Santo State $\left(19^{\circ}-20^{\circ} \mathrm{S}\right)$. The newly discovered reefs harbour a relatively rich and abundant reef community, with 73 fish and 14 benthic cnidarian species, including endangered and commercially important ones. We discuss on urgent needs of properly mapping and understanding the ecological functioning of this reef system. Information provided here is a baseline for future impact evaluations, particularly considering the recent worst environmental disaster of Brazil from a dam collapse in Doce river that affected the region.
\end{abstract}

(c) 2016 Elsevier Ltd. All rights reserved.

\section{Introduction}

The Abrolhos Bank is situated between $16^{\circ} 40^{\prime}-19^{\circ} 40^{\prime} \mathrm{S}$ and $37^{\circ} 20^{\prime}-$ $39^{\circ} 10^{\prime} \mathrm{W}$ (Fig. 1 ) on the eastern Brazilian continental shelf and is recognized as the largest and richest coral reef system in the South Atlantic (Dutra et al., 2005; Freitas et al., 2011; Francini-Filho et al., 2013). The reef systems known until now are concentrated in the northern portion of the Abrolhos Bank and are protected by a mosaic of marine protected areas with different conservation levels (Francini-Filho and Moura, 2008). Brazilian reefs have relatively low fish and scleractinian coral species richness in comparison to other regions, but high endemism levels (about 25\% for fishes and 30\% for scleractinian corals; Moura, 2000; Leão et al., 2003). Most reef structures display a characteristic form of mushroom-shaped pinnacles, which attain 5 to $25 \mathrm{~m}$ in height

\footnotetext{
* Corresponding author at: Universidade Federal do Espírito Santo, Departamento de Oceanografia e Ecologia, Av. Fernando Ferrari, 514 - Goiabeiras, Vitória, Espírito Santo 29075-910, Brazil

E-mail address: ericmazzei@hotmail.com (E.F. Mazzei).
}

and 20 to $300 \mathrm{~m}$ across their tops (Francini-Filho et al., 2013). The Abrolhos Bank also encompasses the world's largest continuous rhodolith bed (Amado-Filho et al., 2012), euphotic (<30 m depth) and mesophotic (30-150 m depth) reefs (Moura et al., 2013), as well as sinkhole-like depressions locally known as "buracas" (Bastos et al., 2013).

It was previously thought that the southern part of the Abrolhos Bank was an area dominated by unconsolidated sediments (sand or terrigenous mud) and devoid of reefs, given its proximity to large river discharges, particularly that of the Doce river (Knoppers et al., 1999; Moura et al., 2013). However, this assumption was recently refuted by sidescan sonar studies, which recorded extensive rhodolith beds with sparse mesophotic reefs in the southern Abrolhos Bank (Moura et al., 2013), as well as the presence of biogenic reefs as far south as the Espírito Santo State (Teixeira et al., 2013). The southern Abrolhos Bank was never recognized as a research priority, preventing bona fide progress in coral reefs studies and leaving these large unexplored reefs virtually unknown by the scientific community. Information provided here is an important baseline for future impact evaluations, particularly 


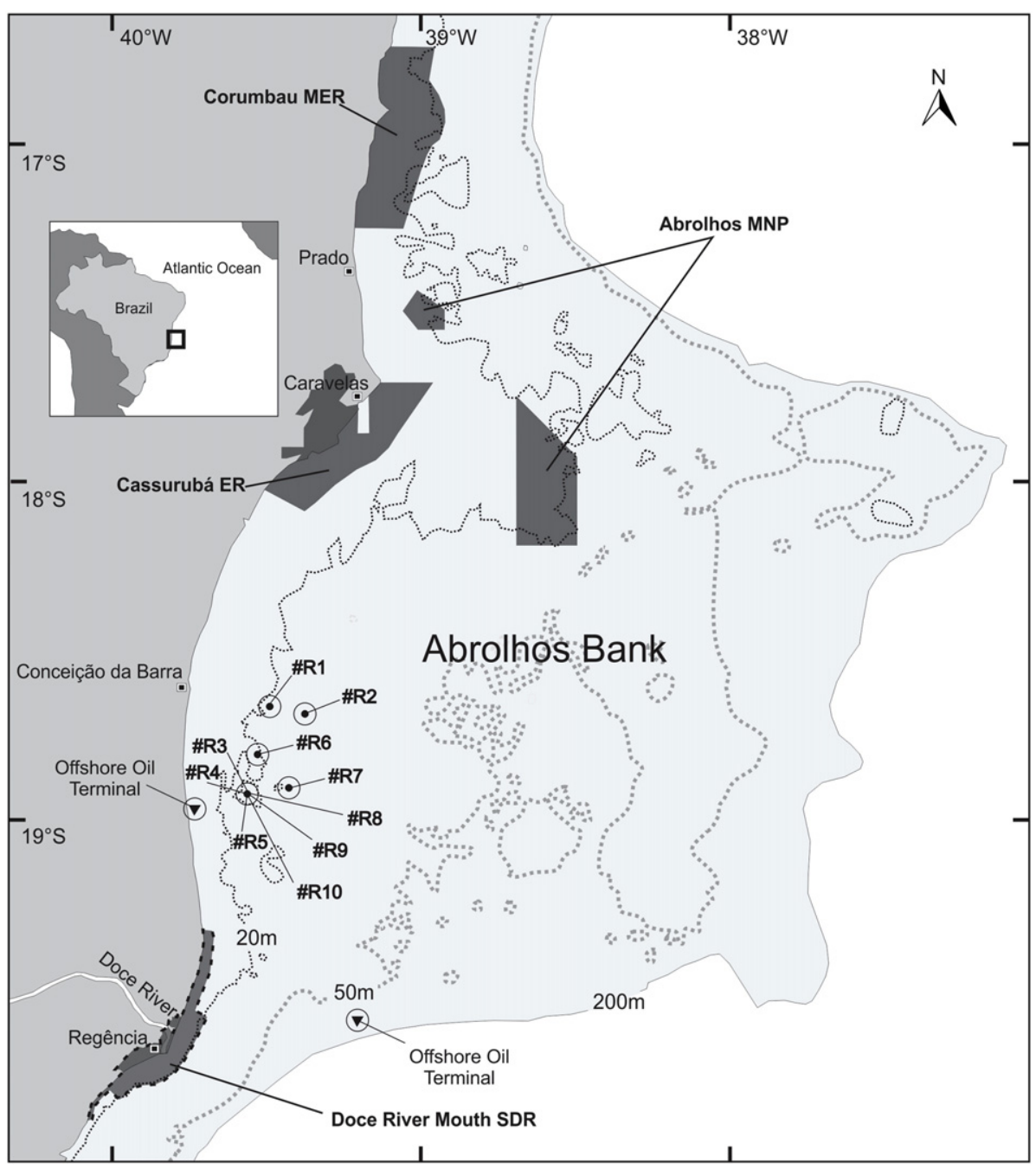

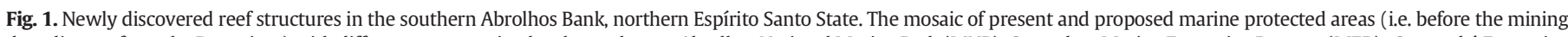

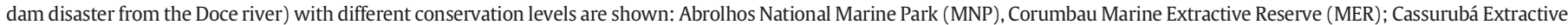
Reserve (ER) and the Doce river Mouth Sustainable Development Reserve (SDR), this latter still a proposal not yet implemented.

considering that the region was recently affected by a huge plume of iron mining waste from a dam collapse in Doce river, now considered the worst environmental disaster in Brazil (Miranda and Marques, 2016).

\section{Materials and methods}

In order to elaborate a baseline assessment of reef biodiversity in the southern Abrolhos Bank, five expeditions were conducted in November 2013, February and December 2014, as well as March and December 2015 (total of 14 days and $24 \mathrm{~h}$ of sampling). During sampling, SCUBA was used to perform rapid visual survey, underwater photography and video, thus generating a checklist of species for each site. Sites ranged between 17 and $28.5 \mathrm{~km}$ offshore and 75-102 km from the Rio Doce River mouth.

\subsection{Fish sampling}

Fishes were identified at the species level, following Craig and Hastings (2007) and Craig et al. (2011) for Epinephelidae, and Westneat and Alfaro (2005) for Labridae. The conservation status of each species was obtained from global (IUCN, 2015), national (MMA, 2014) and regional (IEMA, 2005) red lists (NE: not evaluated; DD: data deficient; LC: least concern; NT: near threatened; VU: vulnerable;
EN: endangered; CR: critically endangered). Geographical distribution of reef fish species [Brazilian province (BR); circumtropical (CT); trans-Atlantic (TA); Western Atlantic (WA); Central Atlantic (CA); Eastern Pacific (EP)] was obtained from Froese and Pauly (2016) and trophic categories were assigned following Ferreira et al. (2004) and FranciniFilho and Moura (2008).

\subsection{Benthic cnidarians sampling}

Coral cover was visually estimated for each reef. Corals were identified at the species level, whenever possible, following SeaLifeBase (Palomares and Pauly, 2016) and their geographical distribution was assigned following FAO Marine Fishing Areas [endemic to the Brazilian province (BR); Western Atlantic (WA); Eastern Central Atlantic (ECA); Western Central Atlantic (WCA), and circumtropical (G)]. The conservation status of each species was obtained from global (IUCN, 2015), national (MMA, 2014) and regional (Espírito Santo State; IEMA, 2005) red lists.

\section{Results}

Ten biogenic reefs (12-25 $\mathrm{m}$ depth, ranging $6-12 \mathrm{~m}$ in height and 20-50 $\mathrm{m}$ in top diameter) were surveyed in the southern portion of the Abrolhos Bank (Figs. 1 and 2). Scleractinian coral cover was slightly 


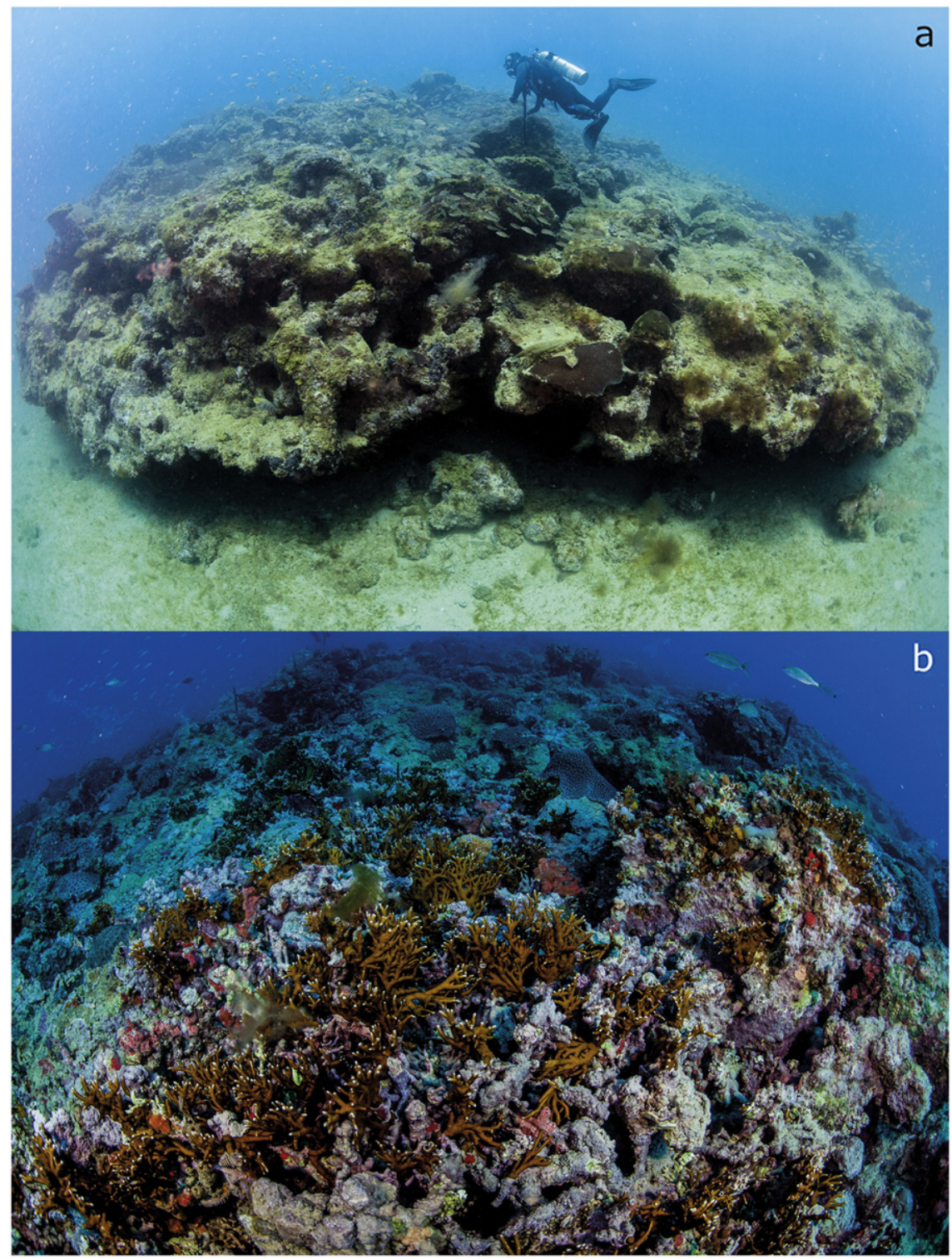

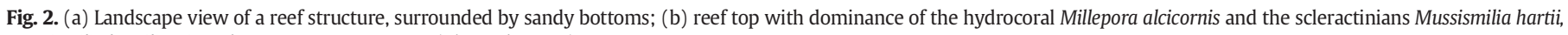
Mussismilia braziliensis and Montastraea cavernosa (Photos by AAB).

lower $(\sim 10-20 \%)$ in comparison to reefs in the northern Abrolhos Bank ( 5-35\%; Francini-Filho et al., 2013). Reef morphology was intermediate between that of typical mushroom-shaped pinnacles ("Chapeirões"; Leão et al., 2003) found in the northern part of the Bank and the small patch reefs found in the central/southern coast of the Espírito Santo State. Information about fish and coral species (geographical range, conservation status and trophic categories) is given in Tables 1 and 2 . respectively.

Large healthy colonies (i.e. no visual signs of bleaching and/or disease) of the corals Montastraea cavernosa, Mussismilia harttii, Mussismilia braziliensis and Millepora alcicornis were found over the top of the biogenic structures, except for a few bleached colonies of $M$. cavernosa (Fig. 2).

A total of 73 reef fish (Table 1 ) and 14 benthic cnidarian taxa (Table 2 ) were recorded. The fish fauna was composed by 34 families and 49 genera. Labridae was the most speciose family ( 9 species), followed by Haemulidae and Carangidae (5 each), Lutjanidae (4) and Acanthuridae (3). The most speciose genus was Sparisoma, with four species, followed by Acanthurus, Haemulon and Lutjanus, with three species each. Sampled reefs sheltered a richer and more abundant fauna than the surrounding rhodolith beds, the former including large, endangered and commercially important reef fishes (Fig. 3). Most families recorded encompassed the carnivorous trophic category ( 27 families and 54 species representing $74 \%$ of the total richness), followed by herbivores ( 4 families and 11 species, 15\%), omnivores (5 families and 7 species, $10 \%$ ) and planktivores (1 family and 1 species, 1\%) (Fig. 4A). The most representative functional groups were mobile invertebrate feeders (13 families, $36 \%$ of all species), followed by strict piscivores ( 3 families, $13 \%$ ), macrocarnivores ( 6 families, 11\%) and omnivores (5 families, 10\%) (Table 1, Fig. 4B).

Most recorded fish species have wide geographical distributions, with $48 \%$ ranging across the WA and $25 \%$ being TA. About $18 \%$ are Brazilian endemics (BR), while 9\% have circumtropical (CT) distribution (Fig. 4C). Five fish species are recognized as threatened with extinction by IUCN (2015), while eleven species are listed on the Brazilian red list (MMA, 2014); only two species are listed on the regional red list (IEMA, 2005) (Table 1, Fig. 4). The vast majority of recorded fish species are classified as not-evaluated or data-deficient on global (43 species 59\%) and regional red lists ( 70 species - 96\%) (Fig. 4D and F). One single species (Epinephelus itajara) is listed as critically endangered, another 
Table 1

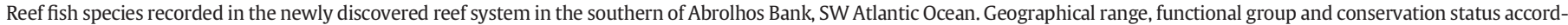

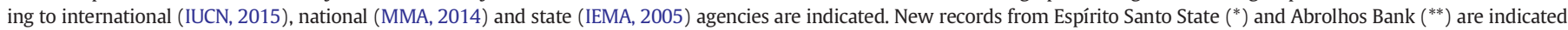

\begin{tabular}{|c|c|c|c|c|}
\hline Family & Species & Geographic distribution & Functional group & Conservation status (IUCN/MMA/IEMA) \\
\hline Albulidae & Albula vulpes (Linnaeus, 1758) & G & SAND & $\mathrm{NT} / \mathrm{NE} /-$ \\
\hline Muraenidae & Gymnothorax vicinus (Castelnau, 1855) & $\mathrm{TA}$ & MCAR & $\mathrm{NE} / \mathrm{DD} /-$ \\
\hline \multirow[t]{2}{*}{ Synodontidae } & Synodus aff. intermedius (Spix \& Agassiz, 1829) & WA & PISC & $\mathrm{NE} / \mathrm{LC} /-$ \\
\hline & Synodus synodus (Linnaeus, 1758) ${ }^{* *}$ & $\mathrm{TA}$ & PISC & $\mathrm{LC} / \mathrm{LC} /-$ \\
\hline Ogcocephalidae & Ogcocephalus vespertilio (Linnaeus, 1758) & WA & MINV & $\mathrm{NE} / \mathrm{NE} /-$ \\
\hline Holocentridae & Holocentrus adscensionis (Osbeck, 1765) & $\mathrm{TA}$ & MINV & $\mathrm{NE} / \mathrm{LC} /-$ \\
\hline \multirow[t]{2}{*}{ Serranidae } & Serranus baldwini (Evermann \& Marsh, 1899) & WA & MINV & $\mathrm{NE} / \mathrm{NE} /-$ \\
\hline & Serranus flaviventris (Cuvier, 1829) & WA & MINV & $\mathrm{NE} / \mathrm{NE} /-$ \\
\hline \multirow[t]{4}{*}{ Epinephelidae } & Cephalopholis fulva (Linnaeus, 1758) & WA & MCAR & $\mathrm{LC} / \mathrm{LC} /-$ \\
\hline & Epinephelus itajara (Lichtenstein, 1822) & $\mathrm{TA}$ & PISC & $\mathrm{CR} / \mathrm{CR} / \mathrm{EN}$ \\
\hline & Epinephelus morio (Valenciennes, 1828)* & WA & PISC & $\mathrm{NT} / \mathrm{VU} /-$ \\
\hline & Mycteroperca bonaci (Poey, 1860) & WA & PISC & $\mathrm{NT} / \mathrm{VU} /-$ \\
\hline Grammatidae & Gramma brasiliensis Sazima, Gasparini \& Moura, 1998 & BR & MINV & $\mathrm{NE} / \mathrm{NT} / \mathrm{VU}$ \\
\hline Priacanthidae & Heteropriacanthus cruentatus (Lacepède, 1801)*** & G & MINV & $\mathrm{NE} / \mathrm{LC} /-$ \\
\hline \multirow[t]{5}{*}{ Carangidae } & Alectis ciliaris (Bloch, 1787$)^{* * *}$ & G & MCAR & $\mathrm{LC} /-/-$ \\
\hline & Carangoides bartholomaei (Cuvier, 1833) & TA & PISC & $\mathrm{NE} / \mathrm{NE} /-$ \\
\hline & Caranx crysos (Mitchill, 1815) & TA & PISC & $\mathrm{LC} / \mathrm{NE} / \mathrm{NE}$ \\
\hline & Caranx ruber (Bloch, 1793 ) & G & PISC & $\mathrm{NE} / \mathrm{NE} /-$ \\
\hline & Decapterus macarellus (Cuvier, 1833)* & G & PISC & $\mathrm{NE} / \mathrm{NE} /-$ \\
\hline \multirow[t]{4}{*}{ Lutjanidae } & Lutjanus alexandrei Moura \& Lindeman, 2007* & BR & MCAR & $\mathrm{NE} / \mathrm{LC} /-$ \\
\hline & Ocyurus chrysurus (Bloch, 1791) & WA & MCAR & $\mathrm{NE} / \mathrm{NT} /-$ \\
\hline & Lutjanus jocu (Bloch \& Schneider, 1801) & $\mathrm{TA}$ & MCAR & $\mathrm{NE} / \mathrm{NT} /-$ \\
\hline & Lutjanus synagris (Linnaeus, 1758) & WA & MCAR & $\mathrm{NE} / \mathrm{NT} /-$ \\
\hline \multirow[t]{6}{*}{ Haemulidae } & Anisotremus surinamensis (Bloch, 1791) & WA & MINV & $\mathrm{NE} / \mathrm{NE} /-$ \\
\hline & Anisotremus virginicus (Linnaeus, 1758) & WA & MINV & $\mathrm{NE} / \mathrm{NE} /-$ \\
\hline & Haemulon aurolineatum Cuvier, 1830 & WA & MINV & $\mathrm{NE} / \mathrm{NE} /-$ \\
\hline & Haemulon squamipinna Rocha \& Rosa, 1999* & BR & MINV & $\mathrm{NE} / \mathrm{NE} /-$ \\
\hline & Haemulon plumierii (Lacepède, 1801) & WA & MINV & $\mathrm{NE} / \mathrm{NE} /-$ \\
\hline & Haemulon steindachneri (Jordan \& Gilbert, 1882) & WA/EP & MINV & $\mathrm{LC} / \mathrm{NE} /-$ \\
\hline Sparidae & Calamus pennatula Guichenot, $1868^{*}$ & WA & SAND & $\mathrm{LC} / \mathrm{NE} /-$ \\
\hline \multirow[t]{2}{*}{ Mullidae } & Mulloidichthys martinicus (Cuvier, 1829)** & $\mathrm{TA}$ & SAND & $\mathrm{NE} / \mathrm{NE} /-$ \\
\hline & Pseudupeneus maculatus (Bloch, 1793) & WA & SAND & $\mathrm{NE} / \mathrm{NE} /-$ \\
\hline Kyphosidae & Kyphosus sp. & TA & MALG & $-1-1-$ \\
\hline Chaetodontidae & Chaetodon striatus Linnaeus, 1758 & WA/CA & SINV & $\mathrm{LC} / \mathrm{LC} /-$ \\
\hline \multirow[t]{3}{*}{ Pomacanthidae } & Holacanthus ciliaris (Linnaeus, 1758) & WA/CA & SPON & $\mathrm{NE} / \mathrm{DD} /-$ \\
\hline & Pomacanthus paru (Bloch, 1787) & TA & SPON & $\mathrm{LC} / \mathrm{DD} /-$ \\
\hline & Pomacanthus arcuatus (Linnaeus, 1758) & WA & SPON & $\mathrm{LC} / \mathrm{DD} /-$ \\
\hline Cirrhitidae & Amblycirrhitus pinos (Mowbray, 1927) & WA & MINV & $\mathrm{NE} / \mathrm{DD} /-$ \\
\hline \multirow[t]{3}{*}{ Pomacentridae } & Abudefduf saxatilis (Linnaeus, 1758) & $\mathrm{TA}$ & OMNI & $\mathrm{NE} / \mathrm{LC} /-$ \\
\hline & Stegastes fuscus (Cuvier, 1830) & $\mathrm{BR}$ & THER & $\mathrm{LC} / \mathrm{LC} /-$ \\
\hline & Stegastes variabilis (Castelnau, 1855) & WA & THER & $\mathrm{NE} / \mathrm{LC} /-$ \\
\hline \multirow[t]{9}{*}{ Labridae } & Bodianus rufus (Linnaeus, 1758) & WA & MINV & $\mathrm{LC} / \mathrm{LC} /-$ \\
\hline & Doratonotus megalepis Günther, 1862 & $\mathrm{TA}$ & MINV & $\mathrm{LC} / \mathrm{LC} /-$ \\
\hline & Halichoeres brasiliensis (Bloch, 1791) & $\mathrm{BR}$ & MINV & $\mathrm{DD} / \mathrm{LC} /-$ \\
\hline & Halichoeres poeyi (Steindachner, 1867) & WA & MINV & $\mathrm{LC} / \mathrm{LC} /-$ \\
\hline & Scarus zelindae Moura, Figueiredo \& Sazima, 2001 & BR & SCRP & $\mathrm{DD} / \mathrm{VU}$ \\
\hline & Sparisoma amplum (Ranzani, 1841) & BR & SCRP & $\mathrm{LC} / \mathrm{NT} /-$ \\
\hline & Sparisoma axillare (Steindachner, 1878) & $\mathrm{BR}$ & SCRP & $\mathrm{DD} / \mathrm{VU} /-$ \\
\hline & Sparisoma frondosum (Agassiz, 1831) & BR & SCRP & $\mathrm{DD} / \mathrm{VU} /-$ \\
\hline & Sparisoma tuiupiranga Gasparini, Joyeux \& Floeter, 2003 & BR & SCRP & $\mathrm{LC} / \mathrm{LC} /-$ \\
\hline Blenniidae & Hypleurochilus pseudoaequipinnis Bath, 1994 & WA & MINV & $\mathrm{LC} / \mathrm{LC} /-$ \\
\hline & Hypleurochilus fissicornis (Quoy \& Gaimard, 1824) * ** $^{*}$ & WA & MINV & $\mathrm{LC} / \mathrm{LC} /-$ \\
\hline Labrisomidae & Malacoctenus aff. triangulatus Springer, 1959 & WA & MINV & $\mathrm{LC} / \mathrm{LC} /-$ \\
\hline & Malacoctenus delalandii (Valenciennes, 1836) & WA & MINV & $\mathrm{NE} / \mathrm{LC} /-$ \\
\hline Chaenopsidae & Emblemariopsis signifer (Ginsburg, 1942) & WA & MINV & $\mathrm{LC} / \mathrm{LC} /-$ \\
\hline Gobiidae & Coryphopterus dicrus Böhlke \& Robins, 1960 & WA & MINV & $\mathrm{NE} / \mathrm{LC} /-$ \\
\hline & Coryphopterus glaucofraenum Gill, 1863 & WA & OMNI & $\mathrm{NE} / \mathrm{LC} /-$ \\
\hline & Coryphopterus thrix Böhlke \& Robins, 1960 & WA & OMNI & $\mathrm{NE} / \mathrm{LC} /-$ \\
\hline & Elacatinus figaro Sazima, Moura \& Rosa, 1997 & BR & MINV & $\mathrm{NE} / \mathrm{VU} / \mathrm{VU}$ \\
\hline Microdesmidae & Ptereleotris randalli Gasparini, Rocha \& Floeter, 2001 & BR & DPLA & $\mathrm{NE} / \mathrm{LC} /-$ \\
\hline Ephippidae & Chaetodipterus faber (Broussonet, 1782) & WA & OMNI & $\mathrm{NE} / \mathrm{LC} /-$ \\
\hline Acanthuridae & Acanthurus bahianus Castelnau, 1855 & WA & SCRP & $\mathrm{LC} / \mathrm{LC} /-$ \\
\hline & Acanthurus chirurgus (Bloch, 1787) & TA & SCRP & $\mathrm{LC} / \mathrm{LC} /-$ \\
\hline & Acanthurus coeruleus Bloch \& Schneider, 1801 & WA/CA & TURF & $\mathrm{LC} / \mathrm{LC} /-$ \\
\hline Sphyraenidae & Sphyraena barracuda (Edwards, 1771) & G & MCAR & $\mathrm{NE} / \mathrm{LC} /-$ \\
\hline Scombridae & Scomberomorus brasiliensis Collette, Russo \& Zavala-Camin, 1978 & WA & MCAR & $\mathrm{LC} / \mathrm{LC} /-$ \\
\hline Balistidae & Balistes capriscus Gmelin, $1789^{* *}$ & $\mathrm{TA}$ & MINV & $\mathrm{NE} /-/-$ \\
\hline & Balistes vetula Linnaeus, 1758 & $\mathrm{TA}$ & MINV & $\mathrm{VU} /-/-$ \\
\hline Monacanthidae & Cantherhines pullus (Ranzani, 1842) & TA & OMNI & $\mathrm{NE} / \mathrm{LC} /-$ \\
\hline & Cantherhines macrocerus (Hollard, 1853) & TA & OMNI & $\mathrm{NE} / \mathrm{LC} /-$ \\
\hline Ostraciidae & Acanthostracion quadricornis (Linnaeus, 1758) & $\mathrm{TA}$ & OMNI & $\mathrm{NE} / \mathrm{LC} /-$ \\
\hline Tetraodontidae & Canthigaster figueiredoi Moura \& Castro, 2002 & BR & SINV & $\mathrm{LC} / \mathrm{LC} /-$ \\
\hline Diodontidae & Chilomycterus reticulatus (Linnaeus, 1758)*** & G & SINV & $\mathrm{NE} / \mathrm{LC} /-$ \\
\hline
\end{tabular}


Table 2

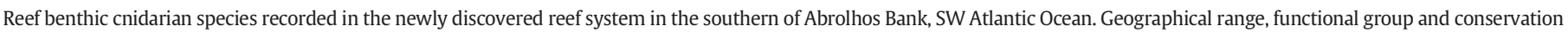
status according to international (IUCN, 2015), national (MMA, 2014) and state (IEMA, 2005) agencies are indicated. New records from Espírito Santo State (*) are indicated.

\begin{tabular}{|c|c|c|c|}
\hline Family & Species & Geographic distribution & Conservation status (IUCN/MMA/IEMA) \\
\hline \multicolumn{4}{|l|}{ Scleractinians } \\
\hline Agariciidae & Agaricia fragilis (Dana, 1848)* & WCA/WA & $\mathrm{LC} / \mathrm{NE} / \mathrm{NE}$ \\
\hline Astrocoeniidae & Madracis decactis (Lyman, 1859) & WA & $\mathrm{LC} / \mathrm{NE} / \mathrm{NE}$ \\
\hline \multirow[t]{2}{*}{ Faviidae } & Favia gravida (Verrill, 1868) & BR & $\mathrm{NE} / \mathrm{NE} / \mathrm{NE}$ \\
\hline & Montastrea cavernosa (Linnaeus, 1766) & $G$ & $\mathrm{NE} / \mathrm{NE} / \mathrm{NE}$ \\
\hline \multirow[t]{5}{*}{ Mussidae } & Mussismilia braziliensis (Verrill, 1867) & $\mathrm{BR}$ & $\mathrm{DD} / \mathrm{VU} / \mathrm{VU}$ \\
\hline & Mussismilia harttii (Verrill, 1868)* & $\mathrm{BR}$ & $\mathrm{DD} / \mathrm{EN} / \mathrm{NE}$ \\
\hline & Mussismilia hispida (Verrill, 1902) & $\mathrm{BR}$ & $\mathrm{DD} / \mathrm{NE} / \mathrm{NE}$ \\
\hline & Mussismilia leptophylla (Verrill, 1868) & $\mathrm{BR}$ & $\mathrm{DD} / \mathrm{NE} / \mathrm{NE}$ \\
\hline & Scolymia wellsii (Laborel, 1967) & WA & $\mathrm{NE} / \mathrm{NE} / \mathrm{NE}$ \\
\hline Poritidae & Porites astreoides Lamarck, $1816^{*}$ & ECA/WCA/WA & $\mathrm{LC} / \mathrm{NE} / \mathrm{NE}$ \\
\hline Siderastreidae & Siderastrea stellata (Verril, 1868) & BR & $\mathrm{DD} / \mathrm{NE} / \mathrm{NE}$ \\
\hline \multicolumn{4}{|l|}{ Hydrocorals } \\
\hline Milleporidae & Millepora alcicornis (Linneaus, 1758) & ECA/WCA/WA & $\mathrm{LC} / \mathrm{NE} / \mathrm{NE}$ \\
\hline \multicolumn{4}{|l|}{ Octocorals } \\
\hline Clavulariidae & Carijoa riisei (Duchassaing \& Michelotti, 1860) & G & $\mathrm{NE} / \mathrm{NE} / \mathrm{NE}$ \\
\hline \multicolumn{4}{|l|}{ Zoanthids } \\
\hline Sphenopidae & Palythoa caribaeorum (Duchassaing \& Michelotti, 1860) & WCA/WA & $\mathrm{NE} / \mathrm{NE} / \mathrm{NE}$ \\
\hline
\end{tabular}

(Balistes vetula) as vulnerable, three as near threatened, 23 as least concern and four as data deficient according to the IUCN (Table 1, Fig. 4D). According to the Brazilian national red list, six species are classified as vulnerable, five as near threatened, 35 as least concern and five as data deficient (Table 1, Fig. 4E). Thirty-eight species were not evaluated by IUCN and 16 by the Brazilian Ministry of Environment. Considering the regional red list, only two species are classified as vulnerable (Table 1, Fig. 4F). Some incongruences between international and national lists were noted, such as the Queen Triggerfish (B. vetula), commonly found at rhodoliths beds surrounding the newly discovered reefs, which is classified as vulnerable according to IUCN (2015), but not evaluated by national lists (IEMA, 2005; MMA, 2014).

The benthic cnidarian fauna was composed by nine families and 14 species (eleven scleractinians, one octocoral, one zoanthid and one hydrocoral) (Table 2). The richest coral (scleractinians plus hydrocorals) families were Mussidae (five species) and Faviidae (two species) (Table 2). The most important reef builders were the Brazilian endemic Mussismilia braziliensis, M. harttii, and M. hispida, along with Siderastrea stellata, Montastrea cavernosa and the hydrocoral Millepora alcicornis. The zoanthid Palythoa caribaeorum showed great coverage (up to $10 \%$ in some portions of the reefs) and the octocoral Carijoa riisei was commonly found on the edges of reef tops. Unidentified species of sponges and sea squirts also made up the benthic reef coverage.

Agaricia fragilis, M. harttii and Porites astreoides are new records for the Espírito Santo State (Leão et al., 2003). Six (42.9\%) of the recorded coral species are endemic to Brazil, the other six (42.9\%) of them ranging across the western Atlantic Ocean and two (14.2\%) with circumtropical distribution (Fig. 5A). The genus Mussismilia is considered a relict from the Tertiary (Laborel, 1970). Mussismilia braziliensis is classified as vulnerable and $M$. harttii as endangered (MMA, 2014; Table 2). Four species (38.5\%) (Agaricia fragilis, Madracis decactis, Millepora alcicornis and Porites astreoides) are considered least concern by the IUCN (2015) (Fig. 5B), while only M. braziliensis is listed as vulnerable on the regional list (IEMA, 2005; Fig. 5D). Although still unpublished, in a recent revaluation of the conservation status of Brazilian corals, $M$. harttii category was upgraded to EN under criteria A2c (Debora Pires et al., unpub. data). Five species are classified as data deficient by the IUCN (2015) and twelve by the MMA (2014) (Fig. 5).

\section{Discussion}

The Abrolhos Bank is recognized as a priority area for biodiversity conservation in the South Atlantic and thus targeted by actions aiming at promoting sustainable use and conservation of natural resources. The Brazilian government considers the area as a high priority for conservation (MMA, 2007), while the World Convention on Biodiversity recognizes it as an Ecologically or Biologically Significant Area (Dutra et al., 2012; CBD, 2014). Finally, the Abrolhos region has been recently included in a proposal of Marine Biosphere Reserve to be submitted to UNESCO (Mazzei et al., 2014).

The Abrolhos Bank and adjacent oceanic environments of the Vitoria-Trindade seamount chain encompass the highest reef-associated biodiversity in the south Atlantic (Leão et al., 2003; Dutra et al., 2005; Lavrado and Ignacio, 2006; Pinheiro et al., 2015a). This region corresponds to an ecological and biogeographic transitional zone between tropical and subtropical marine biotas (Lavrado and Ignacio, 2006; Spalding et al., 2007; Pinheiro et al., 2015b), characterized by the occurrence of range boundaries of multiple species (Andreata and Séret, 1995; Absalão et al., 2006; Paiva, 2006; Serejo et al., 2006). Despite recent mapping surveys across the Abrolhos Bank, the area of the unexplored shallow reefs complex described here was assigned as unconsolidated sediments (see Fig. 8 in Moura et al., 2013). The new reef system of the southern Abrolhos Bank harbours a relatively rich coral community dominated by Brazilian endemics growing over reefs with structural physiography intermediate to that of the mushroomshaped pinnacles to the north and small patch reefs to the south. The reef system studied here is part of a large mosaic of heterogeneous ecosystems that encompasses mangroves, estuaries, coastal rocky islands and the largest continuous rhodolith beds of the world (Leão et al., 2003; Amado-Filho et al., 2012; Mazzei et al., 2014), and thus is key for understanding and conserving this marine hotspot of biodiversity in the south Atlantic.

The richness of reef-associated species found in this study corresponds approximately to $16.5 \%$ of all fishes and $46 \%$ of all reef-building corals known for the Brazilian Province (i.e. 21 native scleractinians and five hydrocoral species) (Leão et al., 2003; Neves et al., 2006, 2008; Amaral et al., 2008; Floeter et al., 2008). Nine reef fish species and three corals species were recorded for the first time for the Espírito Santo State (Leão et al., 2003; Floeter et al., 2008; Simon et al., 2013; Pinheiro et al., 2015b; pers. obs. by the authors) (Tables 1 and 2). Six fish species from seven families were recorded for the first time for the Abrolhos Bank (Moura and Francini-Filho, 2005) (Table 1).

The reefs described here might comprise hundreds of patchy structures according to local fishermen (pers. comm.) and they may play an important role in local fisheries. However, while the Espírito Santo State is recognized as a hotspot for conservation due to the 


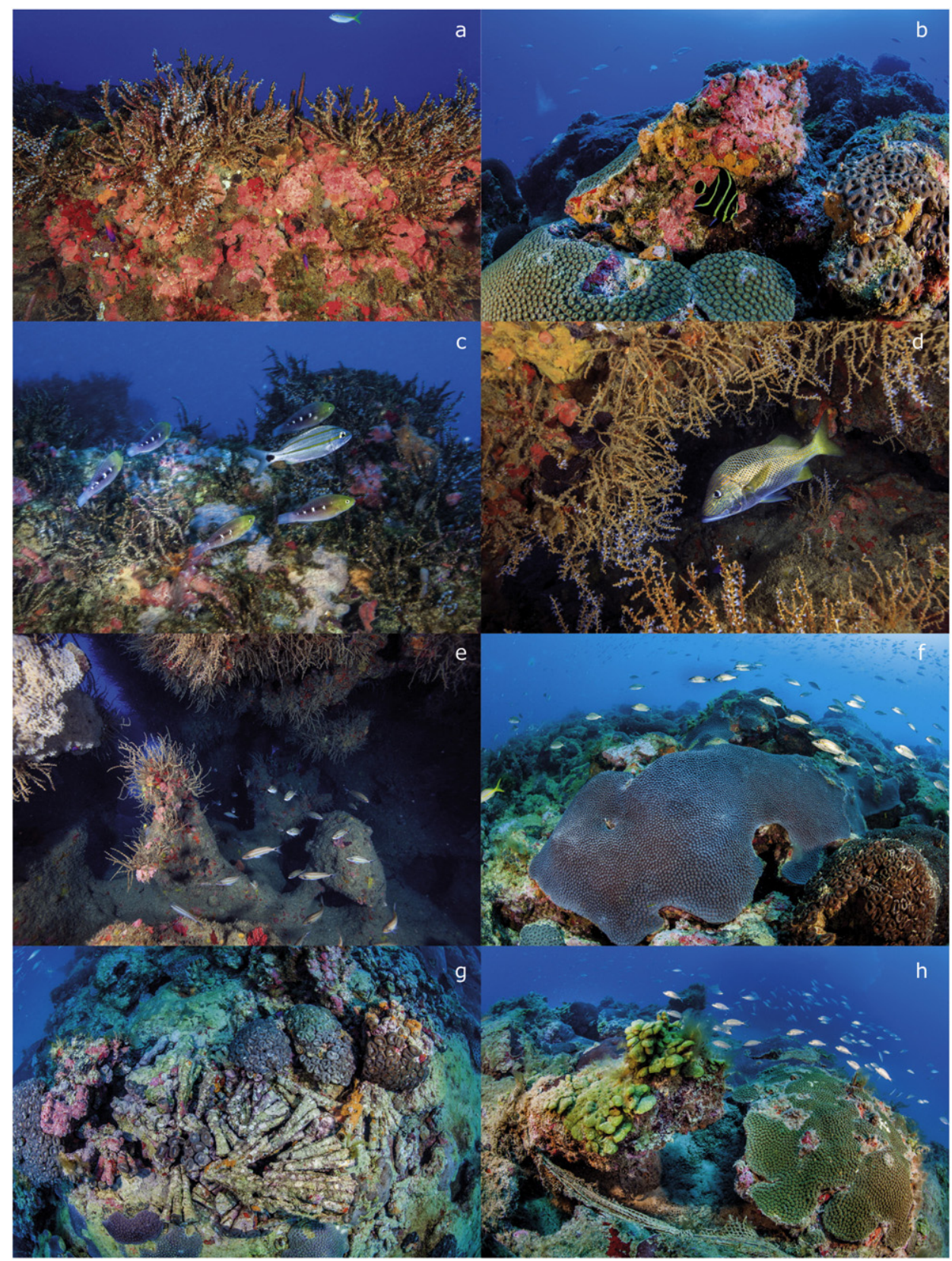

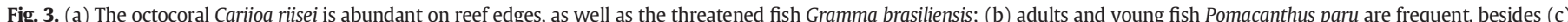

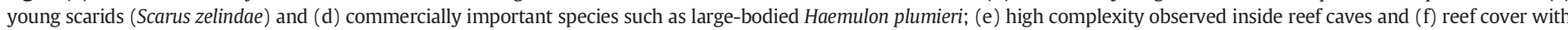

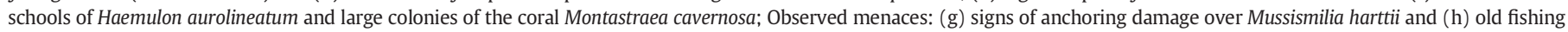
nets embracing sections of a large colony of $M$. cavernosa (Photos by $\mathrm{AAB}$ ).

concentration of threatened, endemic and targeted reef fish species it is, awkwardly, the least protected region along the Brazilian coast (VilaNova et al., 2014). Signs of anthropogenic impacts are already visible in the newly discovered reefs complex, such as anchoring damage and old fishing nets entangled with reef corals (Fig. $3 \mathrm{~g}$, h). In addition, the absence of large predatory fishes as big groupers (Epinephelidae), jacks (Carangidae), sharks and the great dominance of small sized invertivorous reef fishes (i.e. Haemulon aurolineatum) suggest overfishing.

The great majority of species recorded here (60\% for fishes and $77 \%$ for corals) are dada deficient or not evaluated by regional, national and global red lists. This is a worrying pattern considering the plausible increase in anthropogenic impacts in the next decades, such as port expansion, overfishing and mining activities. The recent mining dam collapse in the state of Minas Gerais has produced a flood of $\sim 60$ million tons of toxic mud that moved downstream through the Doce river and reached our study area in the southern Abrolhos Bank (Miranda and Marques, 2016; pers. obs; Figs. 6 and 7). This is already being considered as the worse environmental disaster in Brazil to date (Escobar, 2015). The first analyses of the plume indicate high contamination with heavy metals (i.e. cadmium, lead, iron and arsenic) with concentrations far beyond the limits permitted by Brazilian law for fishes (arsenic up to 140 times, cadmium up to 12 times and lead up to 5 times higher than allowed limits), shrimp (arsenic up to 88-115 times, cadmium up to 5 times and lead up to 5 times above safe limits) and zooplankton (Bianchini et al., 2016). However, the newly discovered reefs system, located about half the way between the Doce river ( $75 \mathrm{~km}$ from the mouth) and the Abrolhos Archipelago, are still ignored and no effort 
A

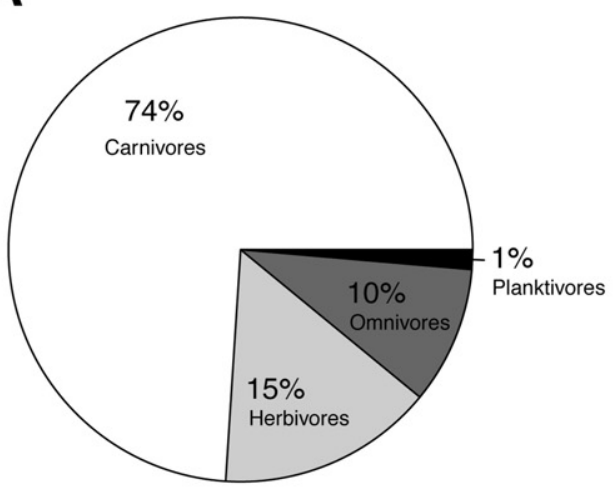

C

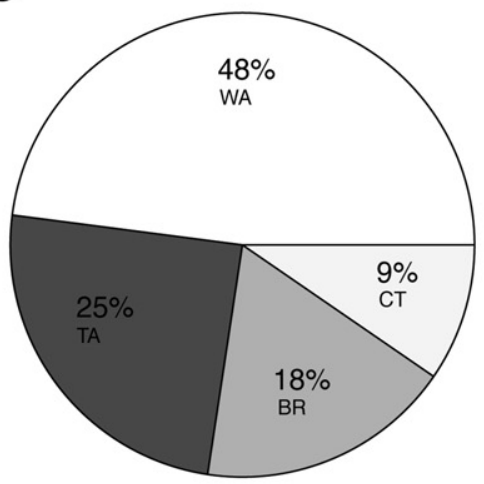

E

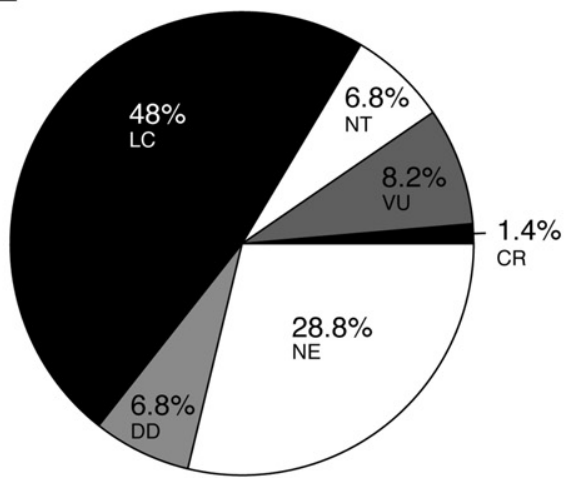

B

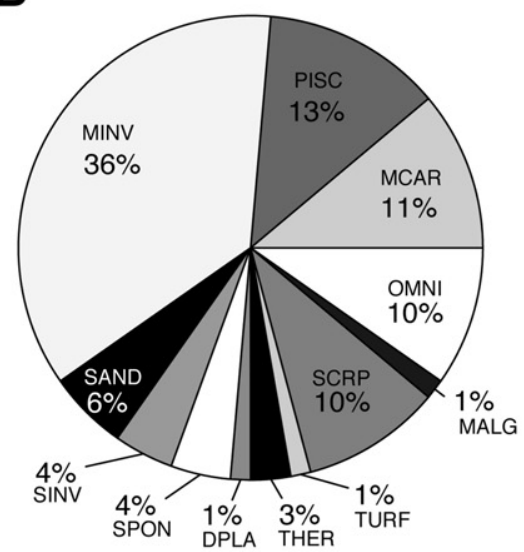

D

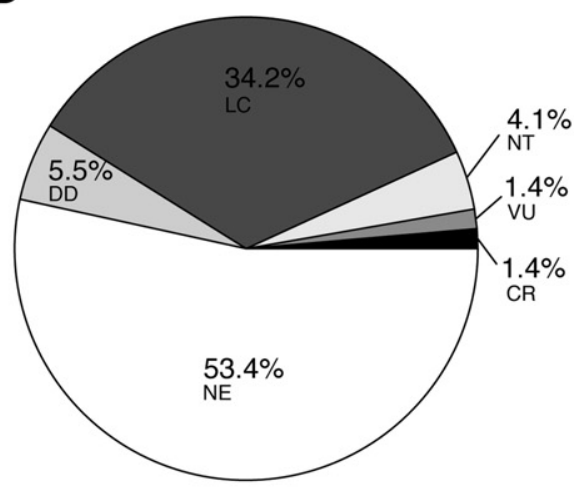

$\mathbf{F}$

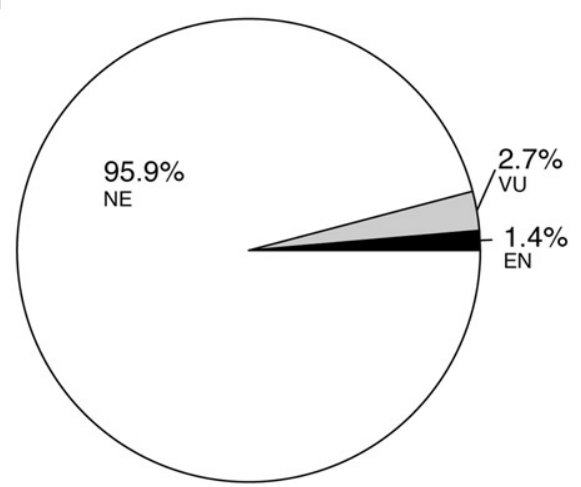

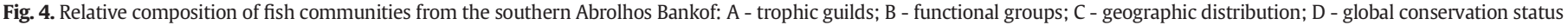
(IUCN, 2015); E - national conservation status (MMA, 2014) and F - regional conservation status (IEMA, 2005).

has been made to monitor and mitigate the environmental impacts of this disaster (Fig. 7).

Potential impacts from the iron mine waste plume to the newly discovered reefs include: i) bioaccumulation and/or biomagnification through food webs (Luoma and Rainbow, 2008); ii) development of toxic algal blooms due to iron fertilization (Flewelling et al., 2005); iii) latent or delayed effects on fish growth, survival and home-range behaviour (Johnson et al., 2007), and endogenous and exogenous chemical synapses' responses (Lürling and Scheffer, 2007). Different pathways for biotic incorporation of sediment-associated and dissolved metals are possible, including uptake by biofilm, plankton or benthos, transference by benthic-pelagic coupling (Farag et al., 1998, 1999), as well as direct exposure of organisms to pollutants (Luoma and Rainbow, 2008).

Finally, four megaprojects of port enterprises are planned to be implemented in the next few years and are actively encouraged by federal, state and local governments. The establishment of ports and industrial megaprojects would bring severe impacts to marine coastal ecosystems and human populations directly dependent on natural resources (Vianna et al., 2012; Ditty and Rezende, 2014). For example, the oil and gas structures already implemented appear to be, at the very least, a potential threat by acting as vectors of invasive species such as the sun coral (Costa et al., 2014) and, possibly, the mud sleeper Butis koilomatodon (Macieira et al., 2012).

\section{Conclusions}

The southern Abrolhos Bank is part of a proposed mosaic of protected areas that remains on hold in the Brazilian Ministry of Environment. While the marine spatial planning is stranded, the poorly known reefs complex described here are threatened by the intense ore mine spill pollution among other anthropogenic impacts. However, if adequately implemented and enforced, a mosaic of marine protected 
A

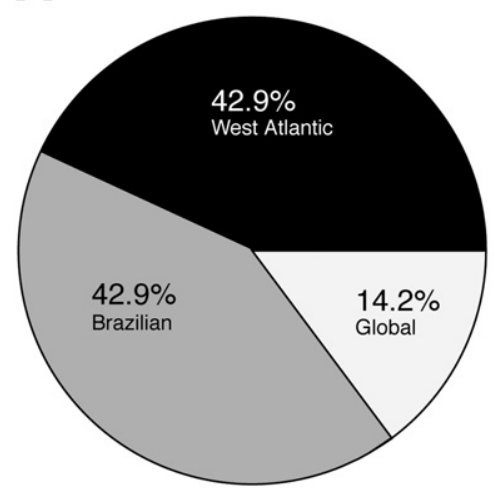

C

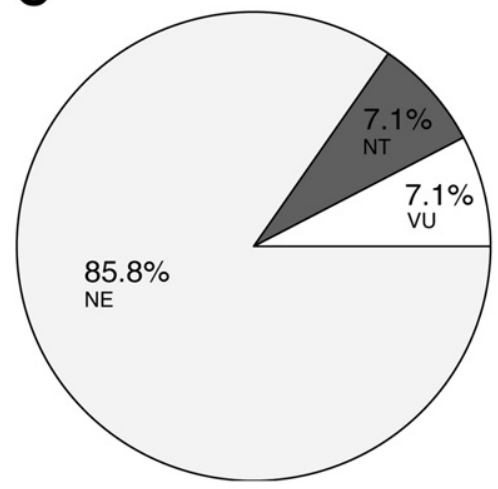

B

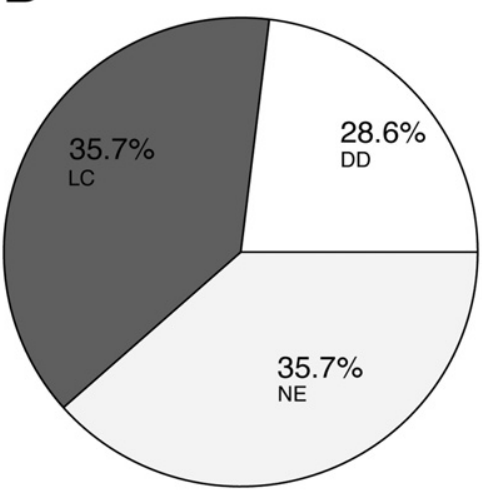

D

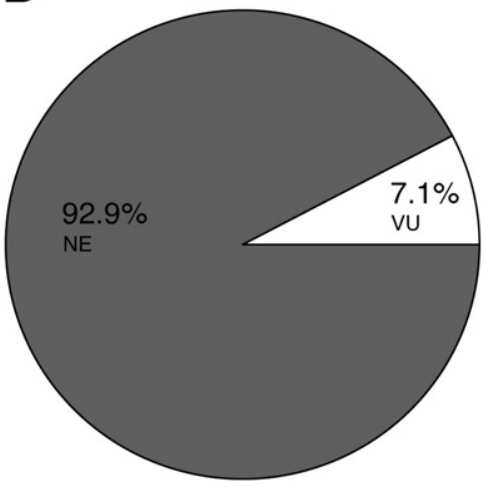

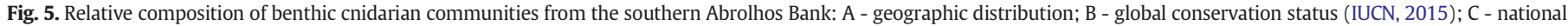
conservation status (MMA, 2014) and D - regional conservation status (IEMA, 2005).

areas (MPAs) would help to maintain the ecological integrity and the biodiversity of the region and create legal paths to mitigate environmental impacts from industrial development.

The fish and coral fauna reported herein are evidence that we still know little about SW Atlantic reef environments. The results provided here are an important baseline on the conditions of reefs before the impacts of the recent mining dam collapse and may also support initiatives for the establishment and planning of marine protected areas over a priority area for biodiversity conservation in the SW Atlantic.

\section{Acknowledgements}

In memory of our great friend and partner Thiony E. Simon, by his geniality, enthusiasm and benevolence. We would like to thank Leandro Rabelo and Johnatas Alves for support in the field. HTP is recipient of doctoral scholarship from CNPq (Ciência sem Fronteiras; GDE 202475/ 2011-5), LFM was supported through a Postdoctoral research fellowship from FAPES/CNPq (54515130/2011) and AAB is recipient of Postdoctoral scholarship from CAPES (PNPD).
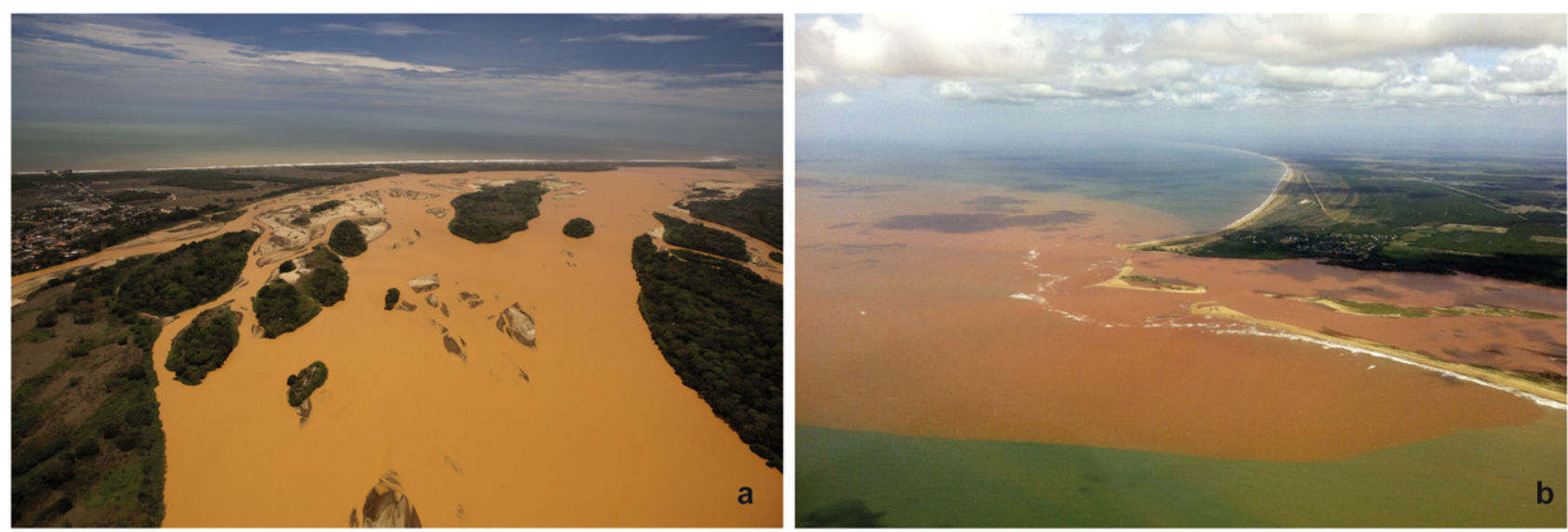

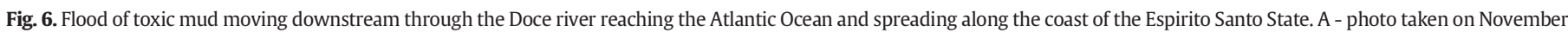
21st, 2015 (looking eastward) and B- February 22nd, 2016 (looking southward) (Photos by Enrico Marcovaldi and EFM, respectively). 


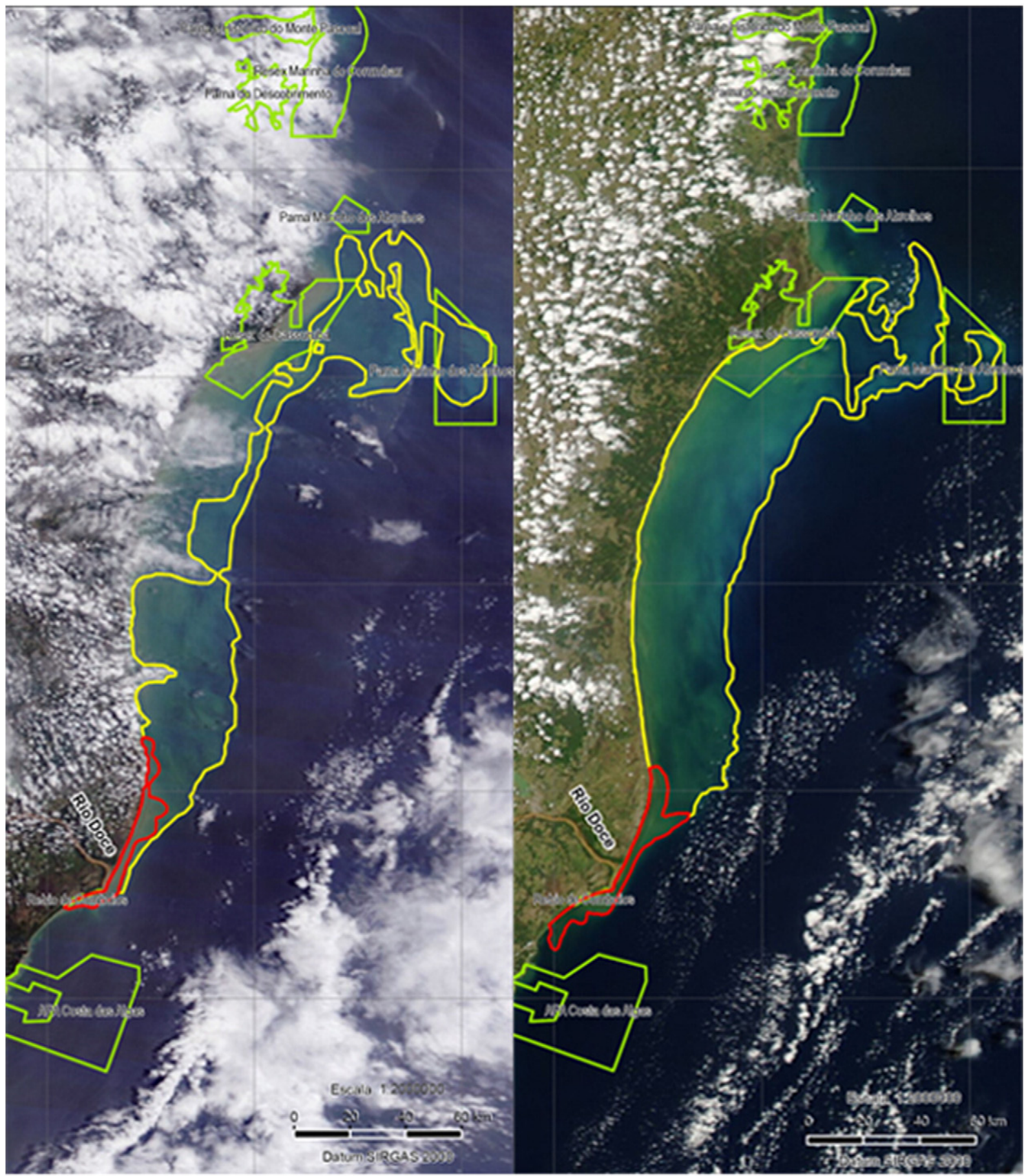

Estimativa de áfea dos poligonos $\left(\mathrm{km}^{2}\right)$

\section{5/01/16}

- pluma de sedimentos de maior concentraçáo: 260 - pluma de sedimentos de menor concentraçâ: 4470

\section{6/01/06}

- pluma de sedimentos de maior concentraçăo: 392 - pluma de sedimentos de menor concentraçăo: 6197 Fonte: NUGEO/SP

Data de Detecçẫ: 06/01/2016

Imagens de Fundo:

Esquerda: TERRAMODIS Fonte: NASAWorldview

Data: OS de janeiro de 2016

Direita: AQUAMODIS Fonte: NASAWorldview Data: 06 de janeiro de 2016

Mapa elaborado pelo Núcleo de Geoprocessamento e

Monitoramento Ambiental da Superintendéncia do IBAMA no Estado de Săo Paulo - NUGEO/SP

\section{Legenda}

$\square$ Pluma de sedimentos de maior concentraçbo

Pluma de sedimentos de menor conoentracáo

$\square$ Unidades de Conservacsoo Federais

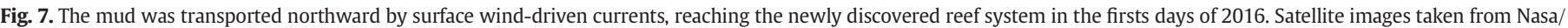

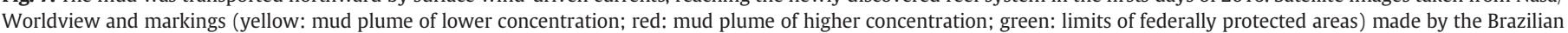
environmental agencies (IBAMA, ICMBio and IEMA). Available at: http://www.governancapelodoce.com.br/pluma/10-a-14022016/. 


\section{Appendix A. Supplementary data}

Supplementary data to this article can be found online at http://dx. doi.org/10.1016/j.marpolbul.2016.08.059.

\section{References}

Absalão, R.S., Caetano, C.H.S., Fortes, R.R., 2006. Filo Mollusca. In: Lavrado, H.P., B.L., I. (Eds.), Biodiversidade Bentônica da Região Central da Zona Econômica Exclusiva Brasileira. Museu Nacional, Universidade Federal do Rio de Janeiro, Rio de Janeiro, pp. 211-259 ISBN 8574270148.

Amado-Filho, G.M., Moura, R.L., Bastos, A.C., Salgado, L.T., Sumida, P.Y., Guth, A.Z., Francini-Filho, R.B., Pereira-Filho, G.H., Abrantes, D.P., Brasileiro, P.S., Bahia, R.G., Leal, R.N., Kaufman, L., Kleypas, J.A., Farina, M., Thompson, F.L., 2012. Rhodolith beds are major $\mathrm{CaCO}_{3}$ bio-factories in the tropical South West Atlantic. PLoS One 7, 5-10. http://dx.doi.org/10.1371/journal.pone.0035171.

Amaral, F.M., Steiner, A.Q., Broadhurst, M.K., Cairns, S.D., 2008. An overview of the shallow-water calcified hydroids from Brazil (Hydrozoa: Cnidaria), including the description of a new species. Zootaxa 1930 (1), 56-68.

Andreata, J.V., Séret, B., 1995. Relação dos peixes coletados nos limites da plataforma continental e nas montanhas submarinas Vitória, Trindade e Martin Vaz, durante a campanha oceanográfica MD-55 Brasil. Rev. Bras. Zool. 12, 579-594.

Bastos, A.C., Moura, R.L., Amado-Filho, G.M., D'Agostini, D.P., Secchin, N.A., Francini-Filho, R.B., Guth, A.Z., Sumida, P.Y.G., Mahiques, M.M., Thompson, F.L., 2013. Buracas: novel and unusual sinkhole-like features in the Abrolhos Bank. Cont. Shelf Res. 70, 118-125. http://dx.doi.org/10.1016/j.csr.2013.04.035.

Bianchini, A., Da Silva, C.C., Lauer, M.M., Jorge, M.B., Costa, P.G., Marques, J.A., Marangoni, L.F., Jesulich, A.C., Taylor, A.J., Luz, D.C., Da-Silva, J.F., Zebral, Y.D., Pinto, M.M., 2016. Avaliação do impacto da lama/pluma Samarco sobre os ambientes costeiros e marinhos (ES e BA) com ênfase nas Unidades de Conservação. 1a Expedição do navio de pesquisa Soloncy Moura do CEPSUL/ICMBio. Ministério do Meio Ambiente. Instituto Chico Mendes de Conservação da Biodiversidade - Icmbio. Diretoria de Pesquisa, Avaliação e Monitoramento da Biodiversidade 62 pp. Available in: http:// www.icmbio.gov.br/portal/publicacoes?id=7862:documentos-rio-doce.

CBD, 2014. Report of the Twelfth Meeting of the Conference of the Parties to the Convention on Biological Diversity. UNEP/CBD/COP/12, Pyeongchang, Republic of Korea http://dx.doi.org/10.1007/s13398-014-0173-7.2 288pp. Available in: https://www. cbd.int/doc/meetings/cop/cop-11/official/cop-11-35-en.pdf.

Costa, T.J.F., Pinheiro, H.T., Teixeira, J.B., Mazzei, E.F., Bueno, L., Hora, M.S.C., Joyeux, J.C., Carvalho-Filho, A., Amado-Filho, G., Sampaio, C.L.S., Rocha, L.A., 2014. Expansion of an invasive coral species over Abrolhos Bank, Southwestern Atlantic. Mar. Pollut. Bull. 85, 252-253. http://dx.doi.org/10.1016/j.marpolbul.2014.06.002.

Craig, M.T., Hastings, P.A., 2007. A molecular phylogeny of the groupers of the subfamily Epinephelinae (Serranidae) with a revised classification of the Epinephelini. Ichthyol. Res. 54, 1-17.

Craig, M.T., Sadovy de Mitcheson, Y.J., Heemstra, P.C., 2011. Groupers of the World: A Field and Market Guide. NISC (Pty) Ltd., Grahamstown 424 pp.

Ditty, J.M., Rezende, C.E., 2014. Unjust and unsustainable: a case study of the Açu port industrial complex. Mar. Policy 45, 82-88. http://dx.doi.org/10.1016/j.marpol.2013.11. 018.

Dutra, G.F., Allen, G.R., Werner, T., McKenna, S.A., 2005. A Rapid Marine Biodiversity Assessment of the Abrolhos Bank, Bahia, Brazil, RAP Bulletin of Biological Assessment 38. Washington, DC, USA. http://dx.doi.org/10.1896/ci.cabs.2005.rap.

Dutra, G., Pinheiro, H.T., Teixeira, J.B., Francini-Filho, R.B., Moura, R.L., Amado-Filho, G.M., Joyeux, J.-C., Mazzei, E.F., Macieira, R., Simon, T.E., Martins, A.S., Neves, T., Pereira, R. Gianuca, D., Engel, M.H., Marcondes, M.C., Silva, G.O., Zerbini, A.N., Ferreira, C.E.L., Thomé, J.C.S.A., Secchi, E.R., Pires, D.O., Luna, F., Falcão, A.P., 2012. Abrolhos Bank and Vitória-Trindade Chain. Ecologically or biologically significant marine areas (EBSAs). Special places in the world's oceans. Areas described as meeting the EBSA criteria at the Convention on Biological Diversity - CBD Wider Caribbean and Western Mid-Atlantic Regional Workshop in Recife, Brazil, 28 February to 2 March 2012. Volume 2: Wider Caribbean and Western Mid-Atlantic Region. pp. 72-75 Available in https://www.cbd.int/marine/ebsa/booklet-02-wcar-en.pdf.

Escobar, H., 2015. Mud tsunami wreaks ecological havoc in Brazil. Science 350, 1138-1139.

Farag, A.M., Woodward, D.F., Goldstein, J.N., Brumbaugh, W., Meyer, J.S., 1998. Concentrations of metals associated with mining waste in sediments, biofilm, benthic macroinvertebrates, and fish from the Coeur d'Alene River Basin, Idaho. Arch. Environ. Contam. Toxicol. 34, 119-127. http://dx.doi.org/10.1007/s002449900295.

Farag, A.M., Woodward, D.F., Brumbaugh, W., Goldstein, J.N., MacConnell, E., Hogstrand, C., Barrows, F.T., 1999. Dietary effects of metals-contaminated invertebrates from the Coeur d'Alene River, Idaho, on cutthroat trout. Trans. Am. Fish. Soc. 128, 578-592.

Ferreira, C.E.L., Floeter, S.R., Gasparini, J.L., Ferreira, B.P., Joyeux, J.C., 2004. Trophic structure patterns of Brazilian reef fishes: a latitudinal comparison. J. Biogeogr. 31, 1093-1106. http://dx.doi.org/10.1111/j.1365-2699.2004.01044.x.

Flewelling, L.J., Naar, J.P., Abbott, J.P., Baden, D.G., Barros, N.B., Bossart, G.D., Bottein, M.Y.D., Hammond, D.G., Haubold, E.M., Heil, C.A., Henry, M.S., Jacocks, H.M., Leighfield, T.A., Pierce, R.H., Pitchford, T.D., Rommel, S.A., Scott, P.S., Steidinger, K.A., Truby, E.W., Dolah, F.M.V., Landsberg, J.H., 2005. Brevetoxicosis: red tides and marine mammal mortalities. Nature 435, 755. http://dx.doi.org/10.1038/nature435755a.

Floeter, S.R., Rocha, L.A., Robertson, D.R., Joyeux, J.C., SmithVaniz, W.F., Wirtz, P., Edwards, A., Barreiros, J.P., Ferreira, C.E.L., Gasparini, J.L., Brito, A., Falcón, J.M., Bowen, B.W. Bernardi, G., 2008. Atlantic reef fish biogeography and evolution. J. Biogeogr. 35, 22-47. http://dx.doi.org/10.1111/j.1365-2699.2007.01790.x.
Francini-Filho, R.B., Moura, R.L., 2008. Dynamics of fish assemblages on coral reefs subjected to different management regimes in the Abrolhos Bank, Eastern Brazil Aquat. Conserv. Mar. Freshwat. Ecosyst. 18, 1166-1179. http://dx.doi.org/10.1002/ aqc.966.

Francini-Filho, R.B., Coni, E.O.C., Meirelles, P.M., Amado-Filho, G.M., Thompson, F.L., Pereira-Filho, G.H., Bastos, A.C., Abrantes, D.P., Ferreira, C.M., Gibran, F.Z., Güth, A.Z. Sumida, P.Y.G., Oliveira, N.L., Kaufman, L., Minte-Vera, C.V., Moura, R.L., 2013. Dynamics of coral reef benthic assemblages of the Abrolhos Bank, Eastern Brazil: Inferences on natural and anthropogenic drivers. PLoS One 8. http://dx.doi.org/10.1371/journal. pone. 0054260 .

Freitas, M.O., de Moura, R.L., Francini-filho, R.B., Minte-Vera, C.V., 2011. Spawning patterns of commercially important reef fish (Lutjanidae and Serranidae) in the tropical western South Atlantic. Sci. Mar. 75, 135-146. http://dx.doi.org/10.3989/scimar.2011. $75 n 1135$.

Froese, R., Pauly, D., 2016. FishBase. World Wide Web electronic publication. www. fishbase.org (version (01/2016)).

IEMA, 2005. Espécies da fauna e flora silvestres ameaçadas de extinção no estado do Espírito Santo. Vitória, Decreto n0 1499-R, de 13 de Junho de 2005. pp. 5-9.

IUCN, 2015. The IUCN Red List of Threatened Species. Version 2015.1. http://www iucnredlist.org (Downloaded on 01 June 2015).

Johnson, A., Carew, E., Sloman, K.A., 2007. The effects of copper on the morphological and functional development of zebrafish embryos. Aquat. Toxicol. 84 (4), 431-438.

Knoppers, B., Ekau, W., Figueiredo, A.G., 1999. The coast and shelf of East and Northeast Brazil and material transport. Geo-Mar. Lett. 19, 171-178. http://dx.doi.org/10. 1007/s003670050106.

Laborel, J.L., 1970. Madreporaires et hydrocoralliaires recifaux des cotes bresiliennes, systematique, ecologie, repartion verticale et geographie. Ann. Inst. Oceanogr. 47, $171-229$.

Lavrado, H.P., Ignacio, B.L., 2006. Biodiversidade Bentônica da Região Central da Zona Econômica Exclusiva brasileira. Museu Nacional 8574270148 379p.

Leão, Z.M.A.N., Kikuchi, R., Testa, V. 2003. Corals and coral reefs of Brazil, in: Cortés, J (Ed.), Latin American Coral Reefs. Amsterdan, pp. 9-52. Available in: www.unb.br/ ig/sigep/sitio090/sitio090.htm.

Luoma, S.N., Rainbow, P.S., 2008. Metal Contamination in Aquatic Environments: Science and Lateral Management. Cambridge Univ. Press, Cambridge, U. K. 573p.

Lürling, M., Scheffer, M., 2007. Info-disruption: pollution and the transfer of chemical information between organisms. Trends Ecol. Evol. 22, 374-379. http://dx.doi.org/10. 1016/j.tree.2007.04.002.

Macieira, R.M., Giarrizzo, T., Gasparini, J.L., Sazima, I., 2012. Geographic expansion of the invasive mud sleeper Butis koilomatodon (Perciformes: Eleotridae) in the Western Atlantic Ocean. J. Fish Biol. 81, 308-313. http://dx.doi.org/10.1111/j.1095-8649.2012. 03285.x.

Mazzei, E.F., Pinheiro, H.T., Teixeira, J.B., Dias, H., Ferreira, C.L., Simon, T., Sforza, R., 2014 Proposta de Reconhecimento da Reserva da Biosfera Marinha Abrolhos - Trindade na Costa central do Brasil. 63pp. Available in http://www.rbma.org.br/rbma/pdf/ bancodosabrolhos_cadeiavitoriatrindade.pdf.

Miranda, L.S., Marques, A.C., 2016. Hidden impacts of the Samarco mining waste dam collapse to Brazilian marine fauna - an example from the staurozoans (Cnidaria). Biota Neotrop. 16. http://dx.doi.org/10.1590/1676-0611-BN-2016-0169.

MMA (Ministério do Meio Ambiente), 2007. Portaria no. 9, de 23 de janeiro de 2007. Diário Oficial da União, seção 1, No. 17 (23 de janeiro de 2007, 55).

MMA (Ministério do Meio Ambiente), 2014. Portaria No. 445 Lista nacional oficial de espécies da fauna ameaçadas de extinção - peixes e invertebrados aquáticos. Diário Oficial da União 245 (seção 1), 126-130 18 de Dezembro de 2014.

Moura, R.L., 2000. Brazilian Reefs as Priority Areas for Biodiversity Conservation in the Atlantic Ocean. 9th International Coral Reef Symposium. Indonesia, Bali.

Moura, R.L., Francini-Filho, R.B., 2005. Reef and shore fishes of the Abrolhos region, Brazil. In: Dutra, G.F., Allen, G.R., Werner, T., McKenna, S.A. (Eds.), A Rapid Marine Biodiversity Assessment of the Abrolhos Bank. Conservation International, Bahia, Brazil, Washington, DC, pp. 40-55.

Moura, R.L., Secchin, N.A., Amado-Filho, G.M., Francini-Filho, R.B., Freitas, M.O., MinteVera, C.V., Teixeira, J.B., Thompson, F.L., Dutra, G.F., Sumida, P.Y.G., Guth, A.Z., Lopes, R.M., Bastos, A.C., 2013. Spatial patterns of benthic megahabitats and conservation planning in the Abrolhos Bank. Cont. Shelf Res. 70, 109-117. http://dx.doi.org/10. 1016/j.csr.2013.04.036.

Neves, E., Johnsson, R., Sampaio, C., Pichon, M., 2006. The occurrence of Scolymia cubensis in Brazil: revising the problem of the Caribbean solitary mussids. Zootaxa (1366), 45-54 http://dx.doi.org/10.15468/knsg3a.

Neves, E.G., Andrade, S.C.S., da Silveira, F.L., Solferini, V.N., 2008. Genetic variation and population structuring in two brooding coral species (Siderastrea stellata and Siderastrea radians) from Brazil. Int. J. Genet. Evol. 132, 243-254. http://dx.doi.org/ 10.1007/s10709-007-9168-z

Paiva, P.C., 2006. Filo Annelida. Classe Polychaeta. In: Lavrado, H.P., Ignacio, B.L. (Eds.) Biodiversidade Bentônica da Região Central da Zona Econômica Exclusiva Brasileira Museu Nacional. Universidade Federal do Rio de Janeiro, Rio de Janeiro, pp. 261-298 ISBN 8574270148 .

Palomares, M.L.D., Pauly, D., 2016. SeaLifeBase. World Wide Web electronic publication. www.sealifebase.org version (01/2016).

Pinheiro, H.T., Mazzei, E., Moura, R.L., Amado-Filho, G.M., Carvalho-Filho, A., Braga, A.C., Costa, P.A.S., Ferreira, B.P., Ferreira, C.E.L., Floeter, S.R., Francini-Filho, R.B., Gasparini, J.L., Macieira, R.M., Martins, A.S., Olavo, G., Pimentel, C.R., Rocha, L.A., Sazima, I., Simon, T., Teixeira, J.B., Xavier, L.B., Joyeux, J.-C., 2015a. Fish biodiversity of the Vitória-Trindade seamount chain, southwestern Atlantic: an updated database. PLoS One 10, e0118180. http://dx.doi.org/10.1371/journal.pone.0118180.

Pinheiro, H.T., Madureira, J.M.C., Joyeux, J.-C., Martins, A.S., 2015b. Fish diversity of a Southwestern Atlantic coastal island: aspects of distribution and conservation in a 
marine zoogeographical boundary. Chem. List. 11 (1615). http://dx.doi.org/10.15560/ 11.2.1615.

Serejo, C., Young, P.S., Cardoso, I.A., Tavares, C.R., Abreu Jr., C.R., 2006. Filo Arthropoda. Sub-Filo Crustacea. In: Lavrado, H.P., Inacio, B.L. (Eds.), Biodiversidade Bentônica da Região Central da Zona Econômica Exclusiva Brasileira, Museu Nacional. Universidade Federal do Rio de Janeiro, Rio de Janeiro, pp. 299-338 ISBN 8574270148 .

Simon, T., Joyeux, J.-C., Pinheiro, H.T., 2013. Fish assemblages on shipwrecks and natural rocky reefs strongly differ in trophic structure. Marine Environment. Res. 90, 55-65. http://dx.doi.org/10.1016/j.marenvres.2013.05.012.

Spalding, M.D., Fox, H.E., Allen, G.R., Davidson, N., Ferdaña, Z.A., Finlayson, M., Halpern, B.S., Jorge, M.A., Lombana, A., Lourie, S.A., Martin, K.D., McManus, E., Molnar, J., Recchia, C.A., Robertson, J., 2007. Marine ecoregions of the world: a bioregionalization of coastal and shelf areas. Bioscience 57, 573-583. http://dx.doi.org/10.1641/ B570707.
Teixeira, J.B., Martins, A.S., Pinheiro, H.T., Secchin, N.A., Leão de Moura, R., Bastos, A.C., 2013. Traditional ecological knowledge and the mapping of benthic marine habitats. J. Environ. Manag. 115, 241-250. http://dx.doi.org/10.1016/j.jenvman.2012.11.020.

Vianna, M., de Andrade-Tubino, M.F., Keunecke, K.A., de Andrade, A.C., da Silva Junior, D.R., Vinicius, P., 2012. Estado atual do conhecimento sobre a ictiofauna Org. In: Meniconi, M.F.G. (Ed.), Baía de Guanabara: Síntese do Conhecimento Ambiental, 1 ed. Petrobras, Rio de Janeiro, pp. 169-195 (v.2).

Vila-Nova, D.A., Ferreira, C.E.L., Barbosa, F.G., Floeter, S.R., 2014. Reef fish hotspots as surrogates for marine conservation in the Brazilian coast. Ocean Coast. Manag. 102, 88-93. http://dx.doi.org/10.1016/j.ocecoaman.2014.09.005.

Westneat, M.W., Alfaro, M.E., 2005. Phylogenetic relationships and evolutionary history of the reef fish family Labridae. Mol. Phylogenet. Evol. 36, 370-390. http://dx.doi.org/10. 1016/j.ympev.2005.02.001. 